\title{
USE OF MEDIA NALAR GAME IN TRAINING SKILL MULTIPLICATION ON DEAF STUDENTS IN PRIMARY SCHOOL $X$ BANDUNG DISTRICT
}

\author{
Djuang Fitriani ${ }^{1}$ \\ ${ }^{1}$ Dinas Pendidikan Jawa Barat \\ 1 djuang_fitriani@yahoo.com
}

\begin{abstract}
The presence of inclusive education needs more attention. Especially in basic education. In the process of learning in children with hearing impairment is the most important thing in the success of learning that is; 1) teacher-student affairs, 2) information legibility and, 3) the appropriate type of tools to clarify the subject matter. Researchers try to use the media game reasoning that if it can help to solve in the practice of multiplication skills. It can also be done in the form of a game, helping students psychologically to learn, possessing appeal as if playing but essentially learning, thus increasing the success of learning deaf children in math skills. The research used is action research school (PTK). The result of the learning of deaf students with media of game reasoning on learning mathematics of mathematics conception happened improvement of significant learning result from pre-test result with post-test, this proves that game reasoning media can improve learning results in mathematics learning mathematics concept in class 4 Elementary School X Regency Bandung
\end{abstract}

Keywords: Inclusive education, Basic education, Deaf Children, Game reasoning, Multiplication Skill.

\begin{abstract}
Abstrak
Kehadiran pendidikan inklusi perlu mendapat perhatian lebih. Terutama pada pendidikan dasar. Dalam proses pembelajaran pada anak tunarungu hal yang terpenting dalam keberhasilan pembelajaran yaitu; 1) keterarahwajahan antara guru dan murid, 2) keterbacaan informasi dan, 3) jenis alat bantu yang cocok untuk memperjelas materi pelajaran. Peneliti mencoba menggunakan media nalar game yang sekiranya dapat membantu pemecahan dalam melatih keterampilan perkalian. Juga bisa dilakukan dalam bentuk permainan, membantu siswa secara psikologis untuk belajar, memiliki daya tarik seolaholah bermain tapi hakekatnya sedang belajar, sehingga meningkatkan keberhasilan belajar anak tunarungu dalam keterampilan matematika. Penelitian yang digunakan adalah penelitian tindakan sekolah (PTK). Hasil belajar siswa tunarungu dengan media nalar game pada pembelajaran matematika konsep matematika terjadi peningkatan hasil belajar yang signifikan dari hasil pre tes dengan post tes, hal ini membuktikan bahwa media nalar game dapat meningkatkan hasil belajar dalam pembelajaran matematika konsep matematika di kelas 4 sekolah dasar X Kabupaten Bandung
\end{abstract}

Kata Kunci: Pendidikan inklusi, Pendidikan dasar, Anak tunarungu, Nalar game, Keterampilan Perkalian.

\section{INTRODUCTION}

The presence of inclusive education needs more attention. Especially in basic education. Inclusive education as an education service that includes children with special needs $(\mathrm{ABK})$ learns with normal children (non-ABK) age in the regular/regular school closest to where they live. Receiving a crew at the nearby Elementary School is a beautiful dream that parents feel having a child with special needs. one of the hearing impairment grade IV in elementary school X Regency of Bandung. 
Mathematics teaching is given in elementary school starting from elementary school children. This shows that the teaching of mathematics is very important. So the number of hours of lessons is more than the other lessons.

Students in primary schools are at the age of 7-12 years including concrete operational phase. According to Piaget in Makmun (1995) concrete operational phase, namely the ability of children in the process of thinking to operate the rules of logic is still bound in the object of a concrete nature. So that required media that can clarify the subject matter so that more quickly understood student.

According to Sukandi (1988: 12) states that good media is a simple medium, cheap, easy to get anywhere, easy to operate and has an attraction that leads to student motivation in learning.

In the process of learning in children with hearing impairment is the most important thing in the success of learning that is; 1) teacher-student affairs, 2) information legibility and, 3) the appropriate type of tools to clarify the subject matter.

In addition, children aged 9-10 years most of the time used to play. By playing children can socialize, according to Ambron (Joseph, 2001) means that socialization as a learning process that leads the child towards the development of a positive social personality, so as to become responsible and effective community members.

As a result of experience, discussions, and observations in schools, teachers and students encountered many difficulties in the implementation of mathematics and Indonesian language learning, especially mathematics in mathematics. Teachers' difficulties include the first in teaching mathematics required a certain technique and methodology that must be mastered in order to teach well and successfully, both the delivery of information through hearing the deaf children have difficulty, this affects the difficulty of teaching mathematics including teaching mathematics, the three teachers difficult to determine the media which is effective in learning mathematical concepts that are packaged in game form.

Therefore researchers try to use the media of reasoning games that if it can help to solve in multiplication skills train. It can also be done in the form of games, helping students psychologically to learn, possessing appeal as though playing but essentially learning, thus increasing the success of learning deaf children in math skills.

\section{METHOD}

The research used is action research school (PTK). Understanding PTK according to the Teaching Team. Subjects in this study were teachers and students of school IV primary 
school X Bandung Baleendah regency Bandung. The reason chose, because of the subject matter according to the curriculum. Data collection techniques used are through observation and test results learning. The type of observation made is open. While the test results include a pre-test, post-test, cycles 1 through 3.

Data analysis GSM Project Team (1999: 43) "Data analysis is a simplifying process of focusing on abstracting, organizing data systematically and rationally to display materials that can be used to compile answers to PTK objectives", Data analysis in PTK according to the three stages:

1. Data reduction is the process of selecting raw data into meaningful information.

2. Exposure data is the process of data appearance in the form of narrative exposure.

3. Data reduction is the process of extracting the essence of the dish of data that has been organized in the form of a solid statement and brief sentences. 


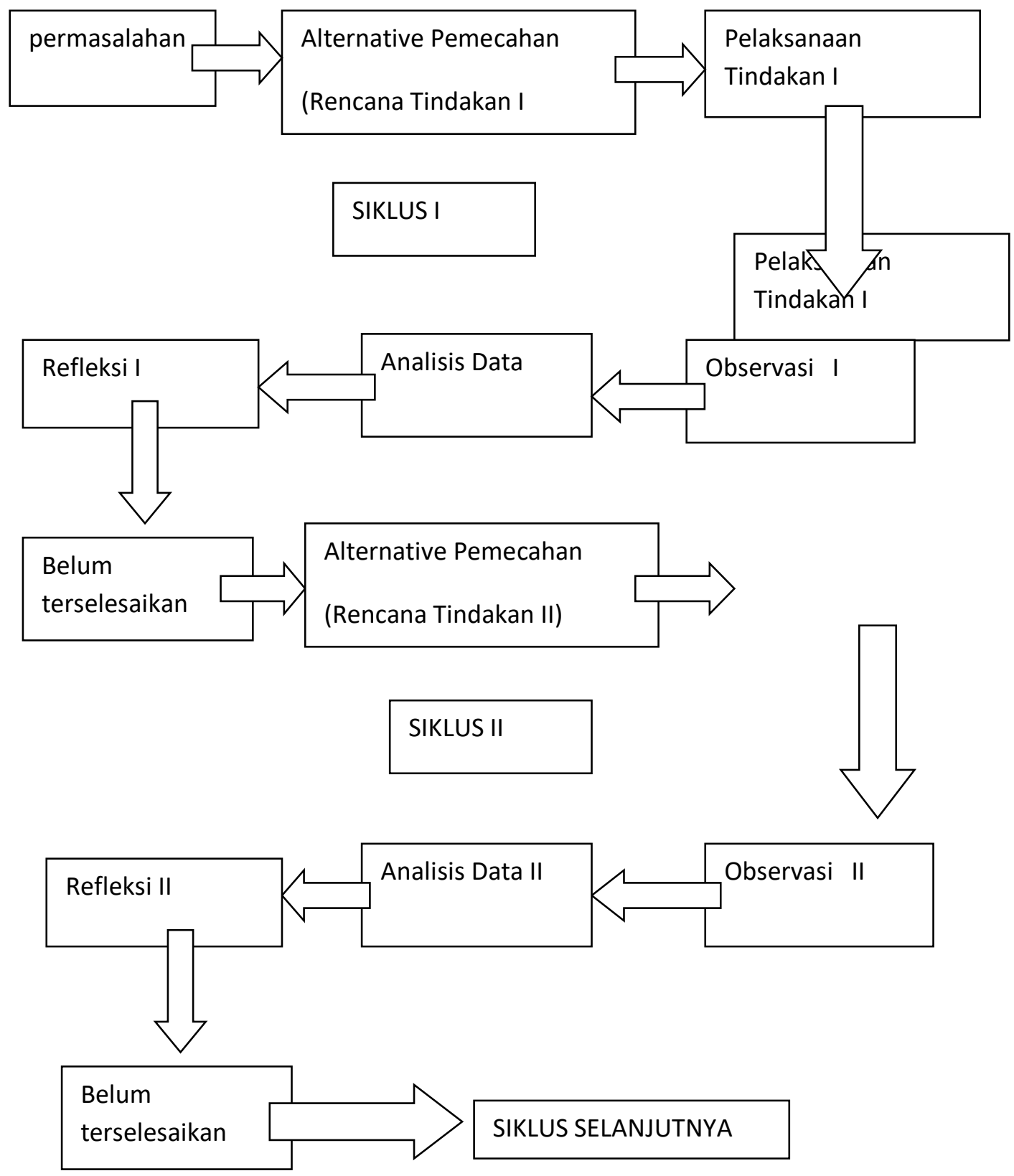

Figure 1. Flow Research

\section{RESULTS AND DISCUSSION}

In this section presented the discussion of research results by presenting some important findings related to the focus of research.

\section{Teacher Activity}

Teacher activity in the learning of mathematics by using the media of game reasoning in the first cycle there are many less of them in the condition of students when opening lessons, giving less example when explaining the material, giving less question spread, less giving 
strengthening especially verbal reinforcement, lacking variation of teaching on aspect voices, movements and subjects, learning is still dominated by teachers, less involving students, and has not seen a member of guidance on small discussions, the use of media is still not less perfect at the time of closing the lessons do not make conclusions.

In the second cycle the teacher activity starts to increase as the students have started to be conditioned when opening lessons, giving examples when explaining the material, asking skill has begun to appear there is spreading, and turn, guide small discussion already exist but not optimal, learning starts involving students, as well as teaching variations. still, need to be improved

In the third cycle, it appears that teacher activity is mostly very good. Teachers already understand how to learn good math by using media game reasoning. This is also the result of continuous reflections trying to improve teacher activity in each cycle. From the observation of teacher activity in every cycle in learning mathematics by using game logic medium, There seems to be a good improvement. This proves that with the media of game reasoning can help improve the activity of elementary school teachers, especially in learning mathematics in grade 4.

\section{Student Activity}

In the first cycle of observation results of student activity, It seems that all aspects observed most of the results are less. Because students are not conditioned to be less passionate and enthusiastic, students are less actively involved, given fewer opportunities to build their own knowledge, less courage to ask and a great deal of reliance on teachers. In the second cycle, the student activity looks better than the previous cycle. This can not be separated from the reflection of observations and discussions between researchers, school teachers, and senior teachers. Although there is still a need to improve, especially the courage of students to ask questions and dependence on teachers that need to be improved, and the use of media who are still afraid of being pierced while taking a dip. In the third cycle, it appears that student activities are mostly very good. Students are increasingly interested and understand how to learn good math by using media game reasoning. This is also due to continuous reflections trying to improve students' activities on each cycle. From the observation of student activity on every cycle in learning mathematics by using game logic medium, there seems to be a good improvement. This proves that with the media of reasoning games can help increase the activity of grade 4 elementary school X Bandung regency, especially in learning mathematics in school

USE OF MEDIA NALAR GAME IN TRAINING SKILL MULTIPLICATION ON DEAF STUDENTS IN PRIMARY SCHOOL X BANDUNG DISTRICT 39 
3. Student Learning Results

Student learning outcomes in this study there are two, namely learning outcomes from the end of each cycle and learning outcomes of three cycles (whole). The learning outcomes of each cycle are three in accordance with the number of planned cycles. In the past, it appears that the level of mastery of the learning outcomes of each cycle appears to be increasing. For more details see Table 1 .

Table 1. Mastery of Students Each Cycle

\begin{tabular}{llll}
\hline No & Cycle & Average & Master rate \\
\hline 1 & One & 4,8 & $48 \%$ \\
2 & Two & 6,4 & $64 \%$ \\
3 & Three & 8,4 & $84 \%$ \\
\hline
\end{tabular}

From the table above It appears that through the media of reasoning game there is an increase in student learning outcomes in learning mathematics every cycle. This shows that the media of game reasoning contributes well in learning mathematics. To see the increase in mastery of student learning from the first cycle to the third cycle more clearly see the following diagram:

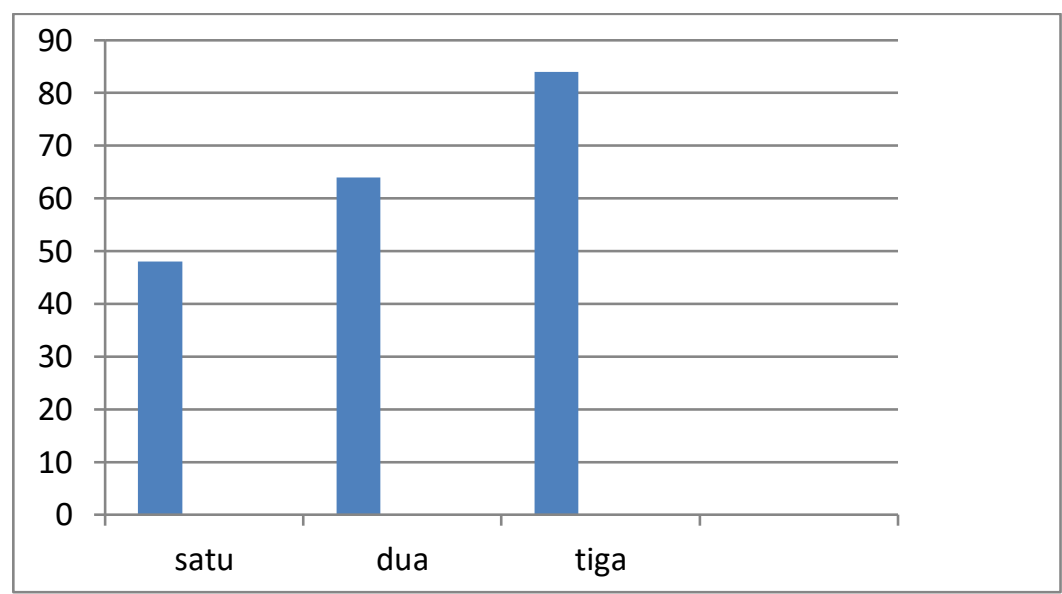

Figure 2. Level of Mastery Learning Each Cycle

Overall learning outcomes are the learning outcomes of the three planned cycles. As previously disclosed that before students are given action is done pre-test, and after the implementation of the overall activities of the cycle carried out post-test. For more details see the results of pre-test and post-test in table 2

Table 2. Mastery Pre-test and Post-test

\begin{tabular}{|c|c|c|c|}
\hline Level of mastery & & Mastery LevelPost- & Differences \\
\hline Pre-test & test & & Mastery Level \\
\hline $42 \%$ & & $80 \%$ & $38 \%$ \\
\hline
\end{tabular}


From the above table It appears that the pre-mastering test of students is only $42 \%$ and after being given the learning of the media of reasoning game mastery of student mastery increased to $80 \%$, the difference is $38 \%$. From these results show that the overall student learning outcomes in learning mathematics concepts mastery of $80 \%$, this means being above average and above the learning level complete $75 \%$. Thus the media of reasoning games can contribute to the learning of mathematical concepts of multiplication.

\section{CONCLUSION}

Based on the results of school action research on "The use of game logic media in learning mathematics on students deaf" conducted in grade 4 elementary school X district Bandung. Can be summed up as follows:

1. Media game reasoning can help and improve teacher activity in mathematics learning mathematics concepts in Class 4 elementary school X District Bandung. This is evidenced by the increased activity of teachers in teaching each cycle.

2. Media game reasoning can help students' activities in mathematics learning mathematics concepts in grade 4 elementary school X District Bandung. This is evidenced by the media reasoning game students increasing activity as well as helping students to learn independently.

3. The result of learning of deaf students with media of game reasoning on learning the mathematics of mathematics conception happened improvement of significant learning result from result of pre-test with post-test, this proves that game reasoning media can improve learning result in learning mathematics concept mathematics in grade 4 elementary school X Regency of Bandung

\section{REFERENCES}

Madigan, M.T., Martinko, J.M., Stahl, D.A.,Clark, D.P. (2010). Brock Biology of Microorganisms, 13th ed. Benjamin Cummings. San Francisco. pp. 42-59.

Asrori, M (2008). Penelitian Tindakan Kelas. Bandung: CV Wacana Prima

Bunawan, L dan Yuniati, CS. (2000). Penguasaan Bahasa Anak Tunarungu. Jakarta: Yayasan Santirama

Bunawan, L (1997). Komunikasi Total. Jakarta: Departemen pendidikan dan Kebudayaan.

Depdiknas. (2003). Sistem Pendidikan Nasional. Jakarta: Wahana Anak Bangsa 
Depdiknas. (2006). Standar Kompetensi LulusanrAnak Tunarungu SDLB. Jakarta: Depdiknas Dirjen Dikdasmen

Depdiknas. (2007). Peraturan Menteri Pendidikan Nasional no 16 tentang Kompetensi Guru. Jakarta: Kemendiknas

Direktorat Pembinaan PKLK Dikdas.(2013) Pedoman Umum Penyelenggaraan pendidikan Inklusif). Jakarta

Kementrian Pendidikan dan kebudayaan Dirjen PKLK Dikdas (2013). Strategi Umum Pembudayaan Pendidikan Inklusif di Indonesia. Jakarta

Hernawati, T. (2007). "Pengembangan Kemampuan Berbahasa dan Berbicara Anak Tunarungu". Jurnal JASSI_anakku. 7, (1), 101-110.

Heruman. (2007). Model Pembelajaran Matematika SD. Bandung: PT Rosda Karya

Harfiani (2013). Penerapan Model Pembelajaran Kontekstual Berbasis Deef Dialogue/ Critical

Thinking untuk Meningkatkan Kemampuan Komunikasi Matematika Siswa SMP (Tesis), Bandung. Universitas Pendidikan Indonesia

Makmun, A.S. (1995). Psikologi Pendidikan. Bandung: Rosda Karya

Mangunsong, F. (2009). Psikologi dan Pendidikan Anak Berkebutuhan Khusus. Depok:

Lembaga Sarana Pengukuran dan Pendidikan Psikologi Kampus Baru Universitas Indonesia.

Nasution, W.W (2006). Penelitian Tindakan Kelas. Jakarta: Universitas Terbuka

Rusman. (2010). Model-model Pembelajaran mengembangkan Profesionalisme Guru. Bandung: PT RajaGrafindo Persada.

Soendari, T. (2010). Pengajaran Individual dalam pendidikan Berkebutuhan Khusus. Bandung:

CV.Catur Mandiri

Somantri.S. (2007). Psikologi Anak Luar Biasa. Bandung: PT Refika Aditama

Sugiyono. (2012). Penelitian pendidikan. Bandung: Alfabeta

Sujana dan Arifin (1998) 1'. Bandung .Sarana Panca Karya

Supinah ( 1999) Media Pembelajaran. Bandung Rosda Karya

Tanireja,T., Pujiarti, I. dan Nyata. (2010). Penelitian Tindakan Kelas. Bandung: Alfabeta

Wardani, Wihardit, K, Nasution,N. (2006) Penelitian Tindakan Kelas. Jakarta: Universitas terbuka 